\title{
THE FERTILITY OF HEIFERS INSEMINATED AT PREDETERMINED INTERVALS FOLLOWING TREATMENT WITH MGA AND HCG TO CONTROL OVULATION
}

\author{
J. F. ROGHE AND J. P. GROWLEY \\ Agricultural Institute, Grange, Dunsany, Co. Meath, Ireland
}

(Received 11th September 1972)

\begin{abstract}
Summary. Oestrus and the time of ovulation were controlled in eighty-seven mature non-pregnant heifers by using silastic implants of MGA followed by an injection of HCG $48 \mathrm{hr}$ after removal of the implants. The heifers were allocated at random to three groups and inseminated with frozen semen before the estimated time of ovulation. Animals in Groups 1 and 2 were inseminated once at 14 and $24 \mathrm{hr}$, respectively, after HCG while animals in Group 3 were inseminated twice 14 and $24 \mathrm{hr}$ after HCG. All heats observed after insemination were recorded until the animals were killed 55 days later, when $23 \%$ of them were found to be pregnant. The conception rate was not affected by changing the time or the frequency of insemination. Possible reasons for the low fertility are discussed.
\end{abstract}

\section{INTRODUCTION}

The oestrous cycle of cattle can be controlled by administering progesterone or one of its synthetic analogues (Lamond, 1964). The number of cows that show heat within a given period of time following treatment has, however, been inconsistent and fertility to natural and artificial matings at this heat is lower than normal (Hansel, 1967; Mauléon \& Chupin, 1971). Both spermatozoa and eggs have a finite life-span in the reproductive tract of the female and their fertilizing ability declines with time. By allowing spermatozoa from different males to compete with each other at different times before ovulation, Dziuk (1970) found that there was a certain interval before ovulation when conception was most likely to take place. This optimum time interval between insemination and ovulation appears to be $12 \mathrm{hr}$ in pigs, rabbits and ewes (Polge, Day \& Groves, 1968; Miller, Roche \& Dziuk, 1969; Dziuk, 1970; Roche \& Crowley, 1971). Consequently, to ensure high fertility, animals should be inseminated in relation to the time of ovulation rather than in relation to the occurrence of heat. In the case of cattle, this necessitates precise control of the time of ovulation at the end of the progestagen synchronizing period.

Graves \& Dziuk (1968) have reported that ovulation occurs about $40 \mathrm{hr}$ 
after an injection of HCG in cows fed 6-methyl-17-acetoxy-progesterone (MAP) for 18 days. The eggs shed as a result of this treatment were capable of normal fertilization. Roche \& Crowley (1972) found that HCG given $48 \mathrm{hr}$ after the removal of a silastic implant of melengestrol acetate (MGA) also controlled the time of ovulation in heifers, with $20 \%$ ovulating by $27 \mathrm{hr}$ after the injection of $\mathrm{HCG}, 73 \%$ by $36 \mathrm{hr}$ and $100 \%$ by $40 \mathrm{hr}$. The aim of the present experiment was to determine if inseminations carried out at prearranged times without reference to heat would give acceptable fertility levels in heifers in which the time of ovulation was controlled as described previously (Roche \& Crowley, 1972).

\section{MATERIALS AND METHODS}

Mature cyclic Hereford X heifers housed in open cubicles and fed on autumn grass silage were used. Animals already pregnant were detect d by rectal examination and discarded before the experiment. Silastic rubber implants, with a surface area of $1307 \mathrm{~mm}^{2}$ and containing $495 \mathrm{mg}$ MGA, were inserted under the skin in the dewlap of eighty-seven heifers for 21 days in December 1971 (Roche \& Crowley, 1973); $48 \mathrm{hr}$ after their removal, 1500 i.u. HCG were injected intramuscularly. The animals were then randomly assigned to three groups and were inseminated at a predetermined time before the estimated time of ovulation without reference to behavioural oestrus. Heifers in Groups 1 and 2 received one insemination; Group I at $14 \mathrm{hr}$ and Group 2 at $24 \mathrm{hr}$ after the injection of HCG. The heifers in Group 3 were inseminated twice, initially at $14 \mathrm{hr}$ and again at $24 \mathrm{hr}$ after HCG. The mean time of occurrence of ovulation in previous work with similar implants of MGA and HCG given at the same time was $34 \mathrm{hr}$ after the injection of HCG (Roche \& Crowley, 1972). Thus, inseminations carried out 14 and $24 \mathrm{hr}$ after HCG were calculated to be 20 and $10 \mathrm{hr}$ before the mean time of ovulation. Frozen semen was used and two artificial insemination (A.I.) technicians from a commercial A.I. station inseminated the animals. Following insemination, all subsequent heats were recorded. The animals were killed 55 days later and their reproductive tracts were examined to determine the number pregnant.

\section{RESULTS}

\section{Occurrence of oestrus}

Oestrus did not occur in any of the experimental heifers while MGA implants were in situ. Following the injection of HCG to induce ovulation, the heifers were observed twice daily for signs of oestrus but none of them was detected in heat. Thus, ovulation occurred unaccompanied by behavioural oestrus.

\section{Fertility}

The fertility of the heifers following all three treatments was very low as only $23 \%$ of the heifers were pregnant at slaughter 55 days after the fixed-time inseminations. The low conception rate was not affected by changing the timing or the number of inseminations. 


\section{Subsequent reproductive performance}

The occurrence of the first recorded repeat heats after insemination showed a significant pattern with four definite peaks occurring. Thirteen heifers had repeat heats between Days 9 and 12 following A.I., eleven heifers repeated between Days 18 and 24, fifteen heifers repeated between Days 28 and 33 and seventeen repeated between Days 38 and 44 . The high frequency of short return intervals suggests that a proportion of the heifers had oestrous cycles of

Table 1. The pregnancy rate in heifers following A.I. at fixed times relative to the estimated time of ovulation

\begin{tabular}{c|c|c|c}
\hline \multirow{2}{*}{$\begin{array}{c}\text { Time of A.I. } \\
\text { before ovulation } \\
(\mathrm{hr})\end{array}$} & $\begin{array}{c}\text { No. of } \\
\text { heifers }\end{array}$ & \multicolumn{2}{|c}{ Heifers pregnant } \\
\cline { 2 - 4 } & & No. & $\%$ \\
\hline 20 & 24 & 6 & 25 \\
10 & 23 & 5 & 22 \\
20 and 10 & 40 & 9 & 23 \\
\hline Total & 87 & 20 & 23 \\
\hline
\end{tabular}

8 to 10 days' duration. The occurrence of these short cycles might also explain the third peak of returns to service at 28 to 33 days if it is assumed that these latter heifers underwent an unobserved or silent heat 9 to 10 days after insemination. In fact, the subsequent cycles of nine of the thirteen heifers with short return intervals were of the normal 18 to 23 days' duration and this suggests that the majority of these early returns to service were accompanied by ovulation.

\section{DISGUSSION}

Following injection of HCG, the heifers did not show heat. This contrasts with the situation when MGA alone is used to synchronize heat (Zimbelman, Lauderdale, Sokolowski \& Schalk, 1970). Others have also found that HCG reduces the incidence of heat in cattle when given in conjunction with progestagens (Mauléon, Rey, Mariana \& Benoit, 1970; Roche \& Crowley, 1972) or when given alone for treatment of ovarian hypoplasia (Nakahara, Domeki \& Yamauchi, 1970).

The mechanism by which HCG suppresses oestrus in these circumstances is not well understood. It is well established that LH stimulates the synthesis of progesterone in luteal tissue both in vivo (Cook, Kaltenbach, Niswender, Norton \& Nalbandov, 1969) and in vitro (Armstrong \& Black, 1966). Zimbelman \& Smith (1966) have shown that the ovaries of heifers treated with MGA contain one characteristic large follicle and preliminary histological evidence indicates that these follicles are highly luteinized (Guthrie, Lamond, Henricks \& Dickey, 1970). These luteinized cells may be stimulated to produce increased amounts of progesterone following the injection of HCG. Increased amounts 
of progesterone before ovulation may inhibit the expression of oestrus since Carrick \& Shelton (1969) have shown that progesterone given in conjunction with oestradiol benzoate has an inhibiting effect on the occurrence of behavioural oestrus in spayed heifers. Failure to show oestrus after the injection of HCG may mean that the mechanisms for normal sperm transport were upset in these heifers.

The reasons for the very low conception rate obtained in all three groups in this experiment are not clear. Both Graves \& Dziuk (1968) and Roche \& Crowley (1972) have established that ovulation is complete in heifers $40 \mathrm{hr}$ after an injection of HCG at the end of the MGA-synchronizing period. During the normal oestrous cycle, however, it has been reported that the interval between the transient LH surge and ovulation is about $24 \mathrm{hr}$ (Schams \& Karg, 1969; Henricks, Dickey \& Niswender, 1970). Thus, the timing of ovulation in relation to the release of LH in animals treated with progestagen and HCG is different to that in normal cyclic animals. This indicates that normal physiological events are upset in synchronized animals receiving HCG.

The normal pattern of follicular growth and development in heifers receiving MGA is altered. The large follicle on the ovary of treated animals histologically appears atretic and contains increased numbers of luteinized cells (Guthrie et al., 1970). There are also fewer small follicles present and high plasma progesterone levels up to $7 \mathrm{ng} / \mathrm{ml}$ have been reported in some treated heifers in which CL were absent. The levels of $\mathrm{LH}$ in serum also tended to be higher than in control heifers. The fertilization rate of eggs shed was low in heifers treated with MGA (Hill, Lamond, Henricks, Dickey \& Niswender, 1971).

It is not clear whether HCG altered the population of follicles that would have ovulated spontaneously at the ensuing normal oestrous periods if no treatment was imposed. Follicles are in a continuous state of growth and atresia and it is only after Day 18 of the cycle that it is possible to identify the follicle that will ovulate at the next oestrous period (Dufour, Whitmore, Ginther \& Casida, 1972). Thus, ovulation of immature or atretic follicles with HCG after the use of MGA could result in the formation of abnormal CL. Since HCG affects steroidogenesis, the pattern of ovarian and follicular steroid production before ovulation could have been altered. Ovarian steroids are known to affect capacitation (Soupart, 1967) and transport of spermatozoa (Quinlivan \& Robinson, 1969) so that significant changes in the endogenous steroid pattern would affect fertilization. Thus, the lowered fertility found following the use of MGA alone was not changed by using HCG to control ovulation. In fact, the use of HCG seemed to have a further deleterious effect on fertility.

The physiological explanation for the occurrence of the short oestrous cycles found is not clear. It would seem that the injection of HCG following the removal of the implant did increase the incidence of such cycles, as earlier workers (Zimbelman et al., 1970) who used MGA in feed for oestrus synchronization did not report their occurrence. Some of the CL formed from the characteristic MGA follicle may have a life-span shorter than normal. In a series of observations on the oestrous cycle of normal Friesian heifers for a period of 1 year, Wishart (1972) found only $1.4 \%$ of the cycles shorter than 18 
days. Macmillan \& Watson (1971) found that $10 \%$ of the cows returning to A.I. in New Zealand returned within the first 17 days and that a distinct peak representing $31.4 \%$ of all short return intervals occurred between 8 and 10 days after the first insemination. It is possible that these short cycles in cattle are more common following A.I. where the possible introduction of diluents or other foreign material into the uterus could cause premature regression of the CL.

In conclusion, this study has shown that the occurrence of oestrus in the heifer can be suppressed with implants of MGA. The results of this experiment also show that the low fertility which is characteristic of matings at the synchronized heat (Zimbelman et al., 1970) is further reduced when HCG is used to control ovulation and insemination is carried out on a fixed-time basis. Though Boyd \& Tasker (1971) did encounter low fertility at the first oestrus following MGA-HCG treatment for oestrus synchronization, they also noted that following the first and second services the fertility in the MGA-HCGtreated group was higher than in untreated or MGA-treated animals. They concluded that the use of MGA and HCG was worthy of further investigation. Earlier work, reviewed by Zimbelman et al. (1970), has revealed the limitations of using MGA alone for oestrus synchronization. The findings of the present study indicate that when MGA is used in combination with HCG for ovulation control, the subsequent fertility is so low that, in our view, such a treatment regimen has little prospect of affording a practical means of allowing all animals to be inseminated on the same day without reference to heat. Other hormones should be tried in an attempt to develop a technique that will give control of ovulation accompanied by normal fertility.

\section{ACKNOWLEDGMENTS}

The authors wish to thank Dr F. J. Harte for facilities provided; Mr D. Prendiville for excellent technical assistance; Dublin District Milk Board for frozen semen used and British Drug House for supplying MGA.

\section{REFERENGES}

Armstrong, D. T. \& Black, D. L. (1966) Influence of luteinizing hormone on corpus luteum metabolism and progesterone biosynthesis throughout the bovine estrous cycle. Endocrinolog', 78, 937.

BOYD, L. J. \& TASKER, J. B. (1971) Fertility of oestrus synchronized dairy cattle treated with gonadotrophins and inseminated at a predetermined time. Vet. Rec. 89, 632.

Garrick, M. J. \& Shelton, J. N. (1969) Oestrogen-progesterone relationships in the induction of oestrus in spayed heifers. 7 . Endocr. 45, 99.

Cook, B., Kaltenbach, G. G., Niswender, G. D., Norton, H. W. \& Nalbandov, A. V. (1969) Short-term ovarian responses to some pituitary hormones infused in vivo in pigs and sheep. 7. Anim. Sci. 29, 711.

Dufour, J., Whitmore, H. L., Ginther, O. J. \& Casida, L. E. (1972) Identification of the ovulating follicle by its size on different days of the estrous cycle in heifers. f. Anim. Sci. 34, 85.

Dzıuk, P. J. (1970) Estimation of optimum time for insemination of gilts and ewes by double-mating at certain times relative to ovulation. 7. Reprod. Fert. 22, 277.

Graves, G. N. \& Dzivk, P. J. (1968) Control of ovulation in dairy cattle with human chorionic gonadotrophin after treatment with $6 \alpha$-methyl-17 $\alpha$-acetoxy-progesterone. 7 . Reprod. Fert. 17, 169.

Guthrie, H. D., Lamond, D. R., Henricks, D. M. \& Dickey, J. F. (1970) Ovarian follicular changes in heifers treated with melengestrol acetate. $\mathcal{F}$. Reprod. Fert. 22, 363. 
Hanse L, W. (1967) Control of the ovarian cycle in cattle. In: Reproduction in the Female Mammal, Proc. 13th Easter School on Agric. Sci., University of Nottingham, p. 419. Eds. G. E. Lamming and E. C. Amoroso. Butterworths, London.

Henricks, D. M., Dickey, J. F. \& Niswender, G. D. (1970) Serum luteinizing hormone and plasma progesterone levels during the estrous cycle and early pregnancy in cows. Biol. Reprod. 2, 346.

Hill, J. R., Lamond, D. R., Henricks, D. M., Dickey, J. F. \& Niswender, G. D. (1971) The effect of melengestrol acetate (MGA) on ovarian function and fertilization in beef heifers. Biol. Reprod. $4,16$.

Lamond, D. R. (1964) Synchronization of ovarian cycles in sheep and cattle. Anim. Breed. Abstr. 32, 269.

Macmillan, K. L. \& Watson, J. D. (1971) Short estrous cycles in New Zealand dairy cattle. F. Dairy Sci. 54, 1526.

Mauléon, P. \& Chupin, D. (1971) Maitrise des cycles sexuels chez les bovins. Écon. Méd. anim. $12,31$.

Mauléon, P., Rey, J., Mariana, J. G. \& Benoit, M. (1970) Possibilités de superovulation après contrôle du cycle oestrien par l'acetate de fluorogestone chez les bovins. Annls Biol. anim. Biochim. Biophys. 10, 65 .

Miller, O. G., Roche, J. F. \& Dziuk, P. J. (1969) Estimation of the optimum interval between insemination and ovulation in the rabbit by double insemination. 7 . Reprod. Fert. $19,545$.

Nakahara, T., Domeki, I. \& Yamauchi, M. (1970) Ovulatory response of quiescent ovary in beef cattle by injecting lower dose of human chorionic gonadotrophin. Jap. 7. Anim. Reprod. 16, 58.

Polge, G., DAy, B. N. \& Groves, T. W. (1968) Synchronization of ovulation and artificial insemination in pigs. Vet. Rec. 83, 136.

Quinlivan, T. D. \& Robinson, T.J. (1969) Numbers of spermatozoa in the genital tract after artificial insemination of progestagen-treated ewes. 7 . Reprod. Fert. 19, 73.

Roche, J. F. \& Growley, J. P. (1971) The effect of controlling the interval from mating to ovulation on pregnancy rate in ewes treated with progesterone. 7 . Reprod. Fert. 24, 307.

Roche, J. F. \& Growley, J. P. (1972) Control of oestrus and ovulation in heifers. In: Proc. 7th Int. Congr. Anim. Reprod. \& A. I. II, 859.

Roche, J. F. \& CRowley, J. P. (1973) The long term suppression of heat in cattle with implants of melengestrol acetate. Anim. Prod. 16, 245.

Schams, D. \& KARG, H. (1969) Radioimmunologische LH-Bestimmung in Blutserum vom Rind unter besonderer Berucksichtigung des Brunstzyklus. Acta endocr., Copenh. 61, 96.

Soupart, P. (1967) Studies on the hormonal control of rabbit sperm capacitation. J. Reprod. Fert. Suppl. 2, 49.

Wishart, D. F. (1972) Observations on the oestrous cycle of the Friesian heifer. Vet. Rec. $90,595$.

Zimbelman, R. G. \& Smith, L. W. (1966) Control of ovulation in cattle with melengestrol acetate. I. Effect of dosage and route of administration. 7. Reprod. Fert. 11, 185.

Zimbelman, R. G., Lauderdale, J. W., Sokolowski, J. H. \& Schalk, T. G. (1970) Safety and pharmacologic evaluations of melengestrol acetate in cattle and other animals: a review. 7 . Am. vet. med. Ass. 157, 1528. 